\title{
HANS JONAS ON THE PERILS OF PROGRESS AND THE RECOVERY OF METAPHYSICAL SPECULATION
}

\author{
Hans Jonas sobre os perigos do progresso e a recuperação da especulação \\ metafísica
}

\author{
Nicholas Allen Anderson \\ Boston College
}

\begin{abstract}
Resumo: A proposição por Hans Jonas de uma ética da responsabilidade implica a simultânea rejeição da noção moderna de progresso e a retomada de uma forma de "especulação metafísica" que ajude os humanos em sua busca por um padrão objetivo de valor. Examinando cuidadosamente a biologia filosófica de Jonas no The Phenomenon of Life e Mortality and Morality, este artigo mostra como o pensamento de Jonas sobre juízos de valor se apoia em sua crítica do progresso e da ciência. A ética do perfeccionismo e do progresso, mostra Jonas, conduz a uma dificuldade na qual a mente moderna tem que navegar entre os perigos presentes nas esperanças hubrísticas do progresso tecnológico e o niilismo que ele encontra no pensamento de Martin Heidegger. A biologia filosófica de Jonas serve como uma crítica dessas posições que possibilita uma orientação alternativa em relação à natureza - uma que funda não só a ética da responsabilidade, mas a atividade especificamente humana da reflexão. A crítica do progresso serve, assim, como uma propedêutica para a ética da responsabilidade e a recuperaão de uma imagem do homem como o animall reflexivo. Tal recuperação da especulação metafísica frente aos dogmas das ciências físicas ajuda a encorajar uma "nova humildade" em face do poder tecnológico do homem. Jonas espera substituir o desejo do homem pela autossuperação com o temor de que sua "não-moderação prometeica" conduzirá à destruição da biosfera. Esse temor reconhece os limites do conhecimento do homem é é, dessa forma, acompanhado por uma postura da ignorância socrática e pelo reengajamento com a philosophia perennis. Ou seja, uma teoria ética menos hubrística depende de uma posição filosófica modesta em relação ao todo. Somente com base nesta modéstia epistemológica podemos esperar chegar ao futuro ao mesmo tempo com cuidado e sabedoria.
\end{abstract}

Palavras-chave: progresso, responsabilidade, ciência modema, tecnologia, metafísico, natureza

\begin{abstract}
Hans Jonas's establishment of an ethics of responsibility entails the simultaneous rejection of the modern notion of progress and the recovery of a form of "metaphysical speculation" that aids man in his search for an objective standard of value. Looking mostly at Jonas's philosophical biology in The Phenomenon of Life and Mortality and Morality, this paper shows how Jonas's thought on value judgments rests upon his critique of progress and science. The ethics of perfectibility and progress, Jonas shows, leads to a predicament in which the modern mind must navigate between the dangers present in the hubristic hopes of technological progress and the nihilism he finds in the thought of Martin Heidegger. Jonas's philosophical biology serves as a critique of these positions that opens up an alternative orientation toward nature-one that grounds not only the ethics of responsibility but the uniquely human activity of reflection. The critique of progress serves, then, as a propaedeutic to the ethics of responsibility and the recovery of an image of man as the reflective animal. Such a recovery of metaphysical speculation from the dogmas of the physical sciences helps encourage a "new humility" in the face of man's technological power. Jonas hopes to replace man's desire for self-overcoming with the fear that his "Promethean immoderation" will lead to the biosphere's destruction. This fear acknowledges the limits of man's knowledge and is thereby accompanied by a posture of Socratic ignorance and the reengagement with the philosophia perennis. That is, a less hubristic ethical theory depends upon a modest philosophical stance toward the whole. Only on the grounds of this epistemological modesty can we hope to proceed into the future with both caution and wisdom.
\end{abstract}

Keywords: progress, responsibility, modem science, technology, metaphysical, nature 


\section{Introduction}

In recent years a number of leading entrepreneurs have made public their ambitions to continue humanity's conquest over nature. We have heard about the desire to establish a colony on Mars by the end of the decade, ${ }^{1}$ the plan to "cure, prevent, or manage all human disease before the end of the century," and even the goal of "solving the problem of death." Such high ambitions, especially the desire to cure death, characterizes the hubris and the "Promethean immodesty" of what Hans Jonas calls the "modern adventure of knowledge." While these projects may attest to the optimistic faith that modern society has in the boundless power of human freedom, ingenuity, and modern science, they are at the same time symptoms of a crisis that has led to the destruction of the environment and the increase of human alienation. By turning to Jonas's works, we can understand the modern impulse toward hubris and find an alternative way of viewing the human being's relationship both with nature and the pursuit of knowledge.

The modern scientific project, Jonas claims, is an "unceasing dynamism," in which "theory has become a function of use as much as use a function of theory." It has led to "the endless forward thrust of life into the ever new, unknown." As a result, our lives, he claims, no longer abide in the present and are determined by "a new realm of necessity" that demands "constant employment in the cave." The scientific and technological world was inspired by the charitable hopes that scientific progress would be a means of relieving man's estate. Jonas places the origin of such hopes in the works of the early modern philosophers Francis Bacon and René Descartes. They sought to liberate man from his original nature through the advancement of science and technology. Jonas claims that these aspirations inadvertently led to man's subjugation to lhis artificial, "second nature." Theory has become subordinated to the new necessity of improving practice for the sake of improving man's material conditions. Consequently, as Roberto Franzini Tibaldeo writes, "technology separates freedom from responsibility, and fails to provide human liberty with the due consideration of the impact of its own deeds. ${ }^{.10}$ In other words, the merging of theory and practice for the sake of material gain does not "leave the meaning of happiness open," and modern science disdains the question "whither goes this unceasing dynamism?"11 The inability or unwillingness of modern man to ask the "extrascientific" questions of value results in his lack of control over the unceasing technological process.

Yet envious of the certainty and continual progress of the natural sciences, contemporary philosophy thinks it should take its cues from science. Philosophy too has become subordinate to man's "second nature" and has become a function of use, seeking

\footnotetext{
${ }^{1}$ Kenneth Chang, "Elon Musk's Plan: Get Humans to Mars and Beyond." The New York Times, September, 28, 2016, https://www.nytimes.com/2016/09/28/science/elon-musk-spacex-mars-exploration.html.

${ }^{2}$ Olivia Solon, "Priscilla Chan and Mark Zuckerberg aim to 'cure, prevent and manage all disease." The Guardian, September 21, 2016, https:/Www.theguardian.com/technology/2016/sep/21/mark-zuckerbergpriscilla-chan-end-disease.

${ }^{3}$ Dara Horn, "The Men Who Want to Live Forever." The New York Times, January 25, 2018, https:/www.nytimes.com/2018/01/25/opinion/sunday/silicon-valley-immortality.html.

${ }^{4}$ Hans Jonas, The Imperative of Responsibility: In Search of an Ethics for the Technological Age, (Chicago, IL: University of Chicago Press, 1984), 201. Hereafter IR.

${ }^{5}$ Hans Jonas, The Phenomenon of Life, ed. Lawrence Vogel (Evanston, IL: Northwestem University Press), 206 Hereafter $P L$

${ }^{6} P L, 209$.

${ }^{7} P L, 208$.

${ }^{8} P L, 209,206$

${ }^{9} P L, 209$.

${ }^{10}$ Roberto Franzini Tibaldeo, "The Heuristics of Fear: Can the Ambivalence of Fear Teach Us Anything in the Technological Age?" Ethics in Progress, Vol.6, No.1 (2015): 227, https://doi.org/10.14746/eip.2015.1.9. ${ }^{11} P I, 208$.
} 
no more than to clear the underbrush from the path of the sciences. Hans Jonas thus observes that two "articles of faith" rule contemporary philosophy" the prohilbition against metaphysics and "the dogma of the sheer subjectivity of values."12 Although Jonas is himself a heretic regarding these dogmas, lhe believes that the nearly overwhelming consensus on these issues should not surprise us since it "reflects the succumbing of philosophy to the success of natural science, which it would like to imitate."13 However, as Jonas points out, this is to fundamentally misconstrue two ways of our being-in-the-world, which, when adequately understood, prove to be complementary forms of rational activity rather than rivals for our allegiance.

Accordingly, Jonas begins from the "organic fact" of biological existence rather than rejecting the findings of natural science. On this ground, Jonas strives to revitalize metaphysical speculation, ground an objective ethical system, and rediscover value in a seemingly indifferent nature. In particular, Jonas's philosophical interpretation of metabolism demonstrates that metaphysical speculation is an extension of this basic natural fact about us as embodied creatures. Metaphysics is thus both a necessary and natural activity of the human being-one grounded in that most basic activity of selfmaintenance.

Jonas's attempt to revitalize metaphysical speculation and ground an objective ethical system is seen most clearly against the backdrop of his critique of the metaphysical assumptions of the modern scientific project-i.e., the framework that constitutes our second nature. Indeed, Jonas's insights into the naturalness of our reflective activities and his hope of overcoming modern dualism are due to his thorough examination of the origins of the modern world. Jonas acknowledges that the modern scientific project arises from a noble aspiration to provide "the foundation of human utility and dignity, ${ }^{\prime \prime 14}$ however, he is skeptical about the hope in the technological and moral progress of humanity, advising that we guide our actions with a "heuristics of fear" in light of our immense power. The optimistic hope for humanity's sovereignty over nature is to be replaced by a sober calculation of the possibly catastrophic consequences of humanity's hubris.

Consequently, Jonas urges the reader to give up the cherished idea of progress, claiming that "the starry-eyed ethics of perfectibility has to give way to the sterner one of responsibility. The latter is not devoid of hope but it gives fear its rightful place."15 Jonas's "heuristics of fear" provides an alternative to the hope in perpetual progress that characterizes the ethics of perfectibility. However, Jonas's heuristics of fear comes as a response to the theoretical and practical failures of the enlightenment hope that moral and political progress will keep pace with the developments of modern science and technology. ${ }^{16}$ The theoretical grounding of Jonas's ethics of responsibility and his emphasis on the place of fear are best understood, then, in light of his critique of progress, perfectibility, and the philosophical foundations of modernity. Jonas's analysis of progress is propaedeutic to his ethical theory.

Moreover, Jonas's critique of progress entails not only a reorientation in our moral lives but a reorientation of philosophy. The ethics of responsibility requires reengaging with the philosophia perennis-that is, the fundamental questions facing

\footnotetext{
${ }^{12}$ Hans Jonas, Mortality and Morality: A Search for the Good After Auschwitz, ed. Lawrence Vogel (Chicago, IL: Northwestern University Press, 1996), 193. Hereafter, MM There are many overlapping arguments between The Phenomenon of Life and Mortality and Morality, often, I will use Jonas's formulations from Mortality and Morality because they are either more succinct or straightforward.

${ }^{13}$ MM, 193.

${ }^{14}$ Immanuel Kant, Critique of Pure Reason, ed. Paul Guyer and Allen Wood, (New York, NY: Cambridge University Press, 1992), B ii. The epigraph to the Critique of Pure Reason is borrowed from Bacon.

${ }^{15} I R, 201$.

${ }^{16}$ For a concise and insightful paper on the relationship between the "heuristics of fear" and the ethics of responsibility, see, Tibaldeo, "The Heuristics of Fear: Can the Ambivalence of Fear Teach Us Anything in the Technological Age?" 225-238.
} 
human beings. ${ }^{17}$ An engagement with such questions serves as a persuasive counterweight against any notion of progress: there are some conditions, problems, and questions that are unresolvable, recurring, or possess only tentative answers. That is, there is something enduringly human across all generations. Moreover, Jonas contends that these problems are faced through a mode of questioning that extends beyond the fact-value distinction that grounds the scientific worldview. Such perennial questions deal with trans-scientific value judgments and thus have political and moral consequences. Through the recovery of a humble yet zetetic orientation toward the unsolvable problems inherent in human nature, Jonas hopes that humanity can face the dire constraints of its technological "second nature." This recovery, however, is made possible by Jonas's critique of the metaphysical and ethical frameworks of the modern world, namely, modern science and the idea of progress.

This essay consists of three sections and a conclusion. In the first section, I will outline Jonas's critique of progress and its basis in modern dualism. The second section clarifies the relationship between philosophic reflection and the ethics of responsibility that comes to light in Jonas's critique of the modern world. The third section further explores Jonas's understanding of "reflection" and the corresponding epistemological modesty accompanying the ethics of responsibility, or what I refer to as Jonas's posture of "Socratic ignorance." Jonas offers the reengagement with the philosophia perenniswhich serves as the condition for recovering the belief in wisdom and objective truth-as an alternative to both modern science and Heideggerian existentialism.

\section{Jonas's critique of the modern idea of progress}

Jonas characterizes the modern idea of progress as "secularized eschatology" that assigns the absolute "a finite place in time," which can be slowly reached through the process of a "teleological dynamism which leads to the final state of affairs" "18 The modern idea of progress relies on the presumption that there is a distance between the way the world ought to be and how life in the world is experienced. Through the doctrine of progress, modern humanity hopes that the gulf between is and ought can be closed over time. The temporalization of the is-ought distinction is the motor of progress. That is, progress temporalizes the absolute represented by the ought, making it something obtainable in this world.

The Kantian distinction between the realm of freedom and the realm of necessity has influenced, if not determined, this modern understanding of the is-ought dynamic. There is an "incalculable gulf" separating nature and freedom, and it is the systems built on this Kantian dualism that ground humanity's hope in the possibility of progress. ${ }^{19}$ Progress, then, is the myth of homo faber. It rests on the belief that nature is there for man and that man can make the world in his image. Nature, understood only in light of the useful, is no longer recognized as a home for man.

However, Jonas's biological writings call into question the way modern thought understands the eschatological motion of the is-ought dynamic by calling into question the distinction between the realm of nature and the realm of freedom. Jonas begins not with Kantian dualism but with the Cartesian separation of res cogitans from res extensa that underlies it. In his genealogy of modern thought, Jonas presents Descartes's separation of mind and matter as the turning away from ancient or medieval teleology ${ }^{20}$ This division of mind and matter is the heart of the "new metaphysic of science," which

\footnotetext{
17 See, MM, 194 .

${ }^{18} I R, 16$.

${ }^{19}$ Immanuel Kant, ed. Paul Guyer and Allen Wood, Critique of the Power of Judgment, (New York, NY:

Cambridge University Press, 2000), 5:176.

20 This genealogy appears most forcefully in the essays "Is God a Mathematician?" and "Philosophical Aspects of Darwinism" in The Phenomenon of Life and in "Seventeenth Century and After: The Meaning of the Scientific and Technological Revolution" in Philosophical Essays.
} 
drains nature "of her spiritual and vital attributes." Jonas continues: "nature is entirely and exclusively [res extensa], i.e., external, while [res cogitans] is in no sense "nature," that division provided the metaphysical charter for a purely mechanistic and quantitative picture of the natural world."21 The separation of the Cartesian subject from nature secures the mathematization, and thereby the mastery of nature: the physical world becomes one homogenous substance whose "essential attribute is extension" and whose "knowledge therefore is essentially in the mode of measurement and mathematical description." ${ }^{\circ 2} 2$

Descartes's separation of mind from matter secures the independence of the measurable but leads to the alienation of the mind due to its "complete ontological detachment" from nature. ${ }^{23}$ In thinking of himself as separate from nature, man feels the tension of being an embodied mind-of his essence being limited by accident. The desire to overcome this tension is the source of the teleological dynamism that drives utopian politics-such teleology is not found in the realm of nature but posited by reason. The ontological detachment of mind from matter leads to the self-understanding that we are not only separate from nature but superior to it.

Here it is helpful to turn to back to Kant, the first great philosopher of progress, and consider his view on the relationship between reason and nature, best seen in his description of the sublime:

The irresistibility of [nature's] power certainly makes us recognize our physical powerlessness, but at the same time it reveals a capacity for judging ourselves as independent of it and a superiority over nature on which is grounded a self-preservation of quite another kind than that which can be endangered by nature outside of us. ${ }^{24}$

Jonas points out that the "theme of [Descartes's] science" ensures the "paradox that reason itself has become an irrational entity." ${ }^{25}$ This anticipates the problem that motivates Kant's critical project-spontaneous reason can know nature but not itself. Kant's "priority of the practical," then, serves as a way of overcoming this "incalculable gulf" through a historical process. Kant's dualism of reason and nature is the result of a moralization of the Cartesian distinction between mind and matter; he transforms the isolation of the res cogitans into a sign of humanity's moral vocation and superiority over nature. The idea of such a moral vocation leads to the modern doctrine of progress. That is, the idea of progress temporalizes and moralizes the dualism inherent in the Cartesian system. The "incalculable gulf" between freedom and nature, mind and matter, is the metaphysical grounds for the idea of a progressive history that seeks to merge is and ought.

According to Jonas, however, dualistic metaphysics cannot account for metabolism, the definitive feature of all organic beings. Jonas claims that such a rift between mind and matter is thereby ill-conceived and that subjectivity is not ontologically distinct from nature but appears in all life down to the unicellular organism. Jonas looks, then, to the fact of metabolism to overcome the dualism inherent in modern thought.

By transforming the material of its environment into its sustenance, the organism "transcends" the mere matter of its environment, which provides the organism with a "basic freedom" that consists in the independence of its "form with respect to its own matter."26 Jonas writes, "The original condition of an organism exhibits individuality as the venture of freedom by which a form maintains its identity through the change of

\footnotetext{
${ }^{21} \mathrm{PL}, 72$.

${ }^{22} P L, 54$. For a more detailed analysis of Bacon and Descartes that supports Jonas's account of the foundations of the modem world, see Richard Kennington, On Modern Origins: Essays in Early Modem Philosophy, (Lanham, MD: Lexington Books, 2004).

${ }^{23} P L, 54$.

${ }^{24}$ Kant, Critique of the Power of Judgment, 5:261.

${ }^{25} \mathrm{PL}, 73$.

${ }^{26} \mathrm{PL}, 81$.
} 
its matter."27 Thus in the biological fact of metabolism, we see in nature the "emancipation of form from matter", there is no "immediate identity" between the organism and the matter that composes it. Yet the price the organism pays for this freedom is death. Sooner or later, it will give in to the "continual crisis" that is the condition of its existence. ${ }^{28}$

Through dealing with this ever-renewing crisis and by issuing a "constant challenge to mechanical nature," life exhibits a concern for itself. ${ }^{29}$ All organic life, insofar as it fights to prolong its existence, possesses inwardness, an awareness of a self that is distinct from the "other" of the surrounding environment. This self-relation is possible only if the organism has the environment as its counterpart by which it distinguishes itself and against which its desires endure over time. In the act of selfmaintenance, life enters into a "horizon of environment" and a "horizon of time" - in short, a world ${ }^{30}$ The more complex the organism, the more complex its "world-relation," and the more mediated is the being's relation to its surrounding environment. Although more complex mediation comes with greater freedom, there is also greater hazard: the more complex the organism, the higher the possibilities for failure.

The different varieties of organism-environment relationships take on a hierarchical structure for Jonas. The more complex the organism, the greater the rewards that arise from its world-relation:

This increased mediacy buys greater scope, internal and external, at the price of greater hazard, internal and external. A more pronounced self is set over against a more pronounced world... [Life's] price from the beginning was mortality, and each further stage of separation pays in its own coin. ${ }^{31}$

Through reason and the representation of images, humans have access to a realm of meaning that all other organisms lack, and with such meaning comes the recognition of value. Man is not separate from nature but the pinnacle of its hierarchical chain; his mediation takes on more significant and riskier forms, but the potential for such mediation is already found in the unicellular organism. Indeed, reason could be understood not simply in terms of an analogy with metabolism but as the most sophisticated form of metabolism. This would be an understanding of metabolism that takes a broader view than the technical biological definition. Still, this understanding would be rooted in Jonas's broad understanding of freedom, which deviates from any "normal understanding of the word."32 Jonas states that metabolism is the "first form of freedom" from which it seems that man's metaphysical activity is the last form of metabolism. The activities of reason and mind, therefore, do not belong to an ontological realm wholly distinct from nature, as Descartes's res cogitans or Kant's transcendental subject.

Nevertheless, with the mind of man, there emerges "a new mode of dealing with the world. " ${ }^{\text {"33 }}$ What begins in metabolism as the "emancipation of form from matter" culminates in man's ability to interact with and transcend his environment through abstract thought.

\footnotetext{
${ }^{27}$ PL, 106. Theresa Morris writes: "Freedom, for Jonas, can be understood in an elementary way as the capacity organisms have to transform matter into form [...] because form is not identical with matter, the individual organism is free from some of the inherent limitations of matter. The organism is thus free from dependence on particular matter" Theresa Morris, Hans Jonas's Ethics of Responsibility, (Albany, NY: SUNY Press, 2013), 60.

${ }^{28} P L_{4} 5$.

${ }^{29}$ Tbid.

${ }^{30} \mathrm{PL}, 85$.

${ }^{31}$ PL, 107

${ }^{32} P L, 3$.

${ }^{33}$ MM, 84.
} 
This theme [of transcendence], common to all life can be traced in its development through the ascending order of organic capabilities and functions: metabolism, motility and appetite, feeling and perception, imagination, art, and thinking-a progressive scale of freedom and danger, reaching its pinnacle in man, who can perhaps understand his uniqueness in a new way if he no longer regards himselif in metaphysical isolation. ${ }^{34}$

Jonas seeks to restore life's "psychophysical unity to its place in theoretical totality." highlighting man's uniqueness within but not his isolation from nature.

In contrast, the modern idea of progress, rooted in notion of the infinite perfectibility of man, takes the human being's "stark foreignness" as a starting point and "confers" meaning by postulating a project that seeks to remake the world in the image of isolated man. The politics of progress and the hopes of utopia stem from this dissatisfied feeling of cosmic loneliness and the concomitant desire to make the world into a home for ourselves. Utopian dreaming, as much as it is a sign of naîve optimism, is also a sign of ingratitude: one is not satisfied with the "venture" and "risk" of being but seeks more from a gift freely given. This sort of ingratitude is easier to foster if one accepts the metaphysical framework of early modern thought, which leaves man "ontologically unsupported" and "estranged from the community of being." ${ }^{\circ 5}$ By restoring the ontological source of value in the purposive activity of the organism, Jonas reopens the possibility that the human being can discover value in the world, he need not posit it.

\section{III.Reflection and responsibility}

The idea of man as the being estranged from nature not only leads him toward that unceasing dynamism in which modern man becomes beholden to the technological world but to a reaction against the feeling of homelessness produced by this new situation of modern thought. Although Jonas's thought reacts against the technological worldview, he sees an equal danger in the manner in which Heidegger's thought opposes technology. Indeed, Jonas's thought stands within the tradition of existentialism, yet he also understands this tradition to be another source of danger for the modern mind. Theresa Morris writes: "The twin dangers, the value-free or value-neutral claim of scientific materialism and the positing of resolute action as authenticity, form the basis for [Jonas's] critique and the spur toward his revaluation of values."36 Much like Martin Heidegger's other notable students, such as Hannalh Arendt, Jacob Klein, Emmanual Levinas, Karl Löwith, and Leo Strauss, Jonas's criticism of Heidegger is accompanied by a great reverence for the profundity of his thought and the recognition that his Destruktion of the Western metaphysical tradition allowed for a fresh reexamination of old philosophical questions. ${ }^{37}$ The danger of the existentialist Destruktion lies in the fact that it leaves modern man with little positive guidance or standard of action beyond that of resolute commitment. Such a position, Jonas argues, is a form of nihilism. ${ }^{38}$ Further, Jonas argues that this form of nihilism results from the historical condition ushered in by the modern scientific worldview and the idea of progress. ${ }^{39}$ That is, Heidegger's analytic of Dasein, Jonas argues, unintentionally expresses the anthropology inherent in the modern project.

Instead of questioning the opinions of the modern scientific worldview, Heidegger took for granted the conclusions following from the supposition of the

\footnotetext{
${ }^{34} M M, 60$.

${ }^{35} \mathrm{PL}, 215,214$. For an extraordinary account of the revolutions in early modern thought and the cosmic loneliness of man, see Alexandre Koyré, From the Closed World to the Infinite Universe. (Baltimore, MD: The John Hopkins Press), 1957.

${ }^{36}$ Moris, Hans Jonas's Ethic of Responsibility, 4.

${ }^{37}$ For Jonas's statement on both his debt and repulsion to Heidegger's thought, see MM, $48-49$.

${ }^{38}$ See, PL, 213.

${ }^{39}$ See, PL, 212 .
} 
separation of res extensa and res cogitans. Consequently, Heidegger's anthropology portrays a picture of man's relationship to nature that mirrors Gnostic theology, yet without a belief in any God. The indifference toward an indifferent nature and the rejection of the idea of a nature where humanity is at home is essential to his rejection of metaphysics. However, the idea of an indifferent nature depends on an unexamined. cosmology and a hidden metaphysics-it is an "abstraction of physical science." That is, the notion of an indifferent nature in which man is the only being who cares is "a remnant from a dualistic metaphysics, to whose use the nonmetaphysical standpoint has no right." ${ }^{\prime 4}$ The use of the metaphysics grounding the modern scientific worldview points to the inconsistency of Heideggerian existentialism, namely "what is the throw without the thrower?"41 Or, as Lawrence Vogel writes, Jonas claims that Heidegger's notion of care "leaves us with nothing worth caring about."42

Jonas argues, then, that Heidegger's existentialism rejects the technological worldview, which obscures the question of Being, yet it depends on the opinions of the metaphysics underlying the very worldview it rejects. However, despite its inconsistency, existentialism is insightful and persuasive, thereby increasing its danger. Since it assumes "the disruption between man and total reality" that is "at the bottom of nihilism," it leads the many persuaded by it into a hopeless situation. Jonas hopes to discover an alternative road open to the modern mind, one that avoids both the hubristic hope of the Promethean project of technological mastery and the despair of being isolated in an indifferent cosmos with the belief that "only a god can still save us." ${ }^{\text {"43 }}$ Once one sees that both of these alternatives rely on a particular view of nature, one can understand the importance of Jonas's philosophical biology in rediscovering a humble yet less despairing understanding of man's place within the cosmos. The need for a philosophical biology, that is, for a reexamination of man's orientation toward nature, can only be felt once one has understood the perils of progress.

Grounding ethics in a reexamination of life is Jonas's proposal for a new framework for the ethical, political, and spiritual challenges of technological modernity, diagnosed but not properly met by Heidegger. As stated above, Jonas's ethical project begins with a reassessment of the "biological facts," namely, the fact of metabolism, the acknowledgment that death is the corollary of life, and that risk is the condition of freedom. Despite the profundity of his thought, Heidegger failed to consider the biological facts and limitations that secure man's worldly experience. This is the meaning of Jonas's statement that Heidegger "failed to bring the statement 'I am hungry' within the purview of philosophy. ${ }^{n 4}$ Jonas's theoretical interest in the organism is thus a repudiation of Heidegger, who never mentions "that side of our nature by means of which, quite externally, we ourselves belong to the world experienced by our senses," i.e., Heidegger's interpretation of inwardness overlooked the body. ${ }_{0}^{45}$

To reiterate, Jonas's philosophical biology simultaneously serves as a critique of

\footnotetext{
${ }^{40} P L, 233$.

${ }^{41}$ Ibid.

${ }^{42}$ Lawrence Vogel, "Hans Jonas's Diagnosis of Nihilism: The Case of Heidegger." Intemational Joumal of Philosophical Studies. 3.1 (1995): 55, https://doi.org/10.1080/09672559508570803. This essay offers a probing and critical reading of Jonas's interpretation of Heidegger. Vogel claims that Jonas's interpretation of Heidegger "overlooks much of the ethical potential of fundamental ontology" and casts doubt on Jonas's claim that Heidegger's thought does not escape the inheritance of Cartesian dualism. Reading Jonas's essay critiquing Heidegger, titled "Gnosticism, Existentialism, and Nihilism," in conjunction with his critique of progress, however, helps one to see the strength in Jonas's position. Such a reading deepens Jonas's critique of Heidegger, since one sees the ways in which Heidegger not only accepts the modern scientific cosmology of an indifferent world but a version of its anthropology, namely the perfectibility of man and his estrangement from nature. That is, Heidegger's analytic of Dasein, and the emphasis on self-projection, is a modulated inheritance of the modern belief that man has no or very few natural limits.

43 "Der Spiegel interview with Martin Heidegger," translated by Jerome Veith, in The Heidegger Reader

(Bloomington, IN; Indiana University Press, 2009), 326.

${ }^{44} \mathrm{MM}, 47$.

${ }^{45}$ Ibid.
} 
the metaphysical framework of modern physical science and as the foundation for a new configuration of the is-ought dynamic. Through the reassessment of the biological facts, Jonas argues persuasively that man's capacity for reflection is continuous with his natural and bodily being, and that reason is not separate from but a part of nature. What distinguishes humanity from the rest of creation is not freedom or inwardness but responsibility, grounded in the capacity for reflection. This insight into the metabolic character of reflection grounds our position of alosolute responsibility for the future of the human species and the biosphere as a whole.

Jonas finds the source of reflection in man's ability to make images. Imagemaking man imposes a symbolic "screen of representations" on the world, ceasing to "see things directly." J46 Jonas writes: "The image is separated from the object, that is, the presence of eidos is made independent of the presence of the thing. ${ }^{\text {"4 }}{ }^{77}$ In the act of image-making, man steps back from the "urgent pressures" of his environment, engages with his world indirectly in a realm of thought, free from the temporal restrictions of the physical world. The capacity for self-reflection emerges once the "subject of all objectification appears as such to itself." ${ }^{m 8}$

True man emerges when the painter of the bull turms to concerning himself with the unpaintable image of his own conduct and the state of his self. Over the distance of this wondering, searching, and comparing perception there is constituted the new entity, "I." This is of all the greatest venture in mediacy and objectification. ${ }^{49}$

In concerning himself with himself, man enters the realm of self-consciousness; he understands himself in terms of an "idea or image of man that is being constantly modified" and under which, willingly or not, he "must live." Reflection implies an image of man; that is, reflection emerges with ethics.

Having become an object for himself, man finds an "immeasurable distance" between himself and the image of "what is man's"-a "gulf" opens between man as subject and as object. In his attempts to overcome this distance man endeavors to "have" himself through the activity of trying to close the gap between subject and object, that is, through the "confrontation of the self with itself." Such reflective activity is expressed in Augustine's famous phrase:

Quaestio mihi factus sum, "I have become a question to myself": religion, ethics, and metaphysics are the never completed attempts to confront this question within the framework of an interpretation of the totality of existence and to find an answer to it. ${ }^{51}$

The never-completed questioning of himself and his environment reflects man's infinite task of striving to close the gap between himself as subject and himself as object. This ability to question is paradigmatic of the "new mode of being" that emerges with true man-one that is the highest form of metabolic exchange between an organism and its environment ${ }^{52}$

This self-conscious questioning is the basis for "the greatest heights and the
${ }^{46} P I_{,} 185$.
${ }^{47} \mathrm{MM}, 81$.
${ }^{48} P L, 185$. Jonas's italics.
${ }^{49} P L, 185$.
${ }^{50} \mathrm{MM}, 84$
${ }^{51}$ Tbid.
${ }^{52}$ By introducing the task of striving to close the gap between subject and object, does Jonas not reintroduce the psychology that drives Kantian or even Hegelian notions of progress? It is possible that Jonas seeks to foster a new orientation toward this tension between subject and object and toward man's desire to have himself. In this sense, Jonas would be appropriating the psychology of German idealism to foster his alternative orientation toward the future. 
deepest depressions of human experience. ${ }^{m 53}$ Through such questions, man interacts with his environment, changes it, thinks along with it, and is changed by it. Humanity forms a distinct kind of ecological niche through its speculative reflections. Further, such reflection is the freest form of organic mediation; yet since each further stage of mediation comes at a cost, man's self-questioning is also the form of mediation that carries the greatest risk. ${ }^{54}$ As Tibaldeo writes, Jonas "points out the essential ambivalence of human freedom" and the risks such ambivalence brings into the "massive employment of technology."55 Man can fail to realize his image and lose that which most distinguishes him from other forms of life while at the same time continuing to wield his immense power over nature.

The possibility of failing to fulfill his essence means that man is uniquely responsible for his being; he has a self-conscious responsibility for his own nature. This self-relation constitutive of human subjectivity is for Jonas the basis of all morality; however, since man's responsibility extends not merely over himself but also his place in nature, speculative reflection and questioning extends from "the individual ego to the whole of existence in which the ego finds itself situated. ${ }^{956}$ Man must continually reflect on his essence and his place within nature. He may be intuitively aware or feel the need to act responsibly in certain cases, but only through his capacity to reflect on the whole can man realize his duty toward the future of the species, his environment, and perhaps even God. In other words, we have the responsibility to follow the Delphic command, "know thyself."

Man answers the question of who he is with "a self-image that is by no means self-evident but is the tentative result of questioning and speculation." Although Jonas rejects the idea of human perfectibility, he does not deny man's malleability. Such malleability explains how humanity could strive to fulfill an idea of man that overlooks essential aspects of its nature. Man's image of himself influences the course of his actions-whether he will act within the limits of his nature or with hubris. Further, the idea of man "demands the presence of its embodiment in the world." 58 We are thus responsible for tending to an idea of man that tells us both "why there should be men" and "how they should be."59 The human organism continually shapes the image of himself through his speculative interactions with his environment; such an image is a form that endures the decay of its creator's matter. The image of man is selftransformative and self-relating, but most of all, it is precarious. The human being has, then, an "ontological imperative" rooted in the nature of his metabolic being to care for such a precarious image through the never-completed inquiries into his own being. ${ }^{60}$

\section{IV.Socratic ignorance and metaphysical speculation}

Jonas tends to the image of man in a way that is in stark contrast with the image of man offered by the theorists of modern progress. Jonas insists on the necessity of metaphysical speculation, for man's moral responsibility cannot be separated from his ability to engage in inquiries into the nature of his own being. The alternative way open

${ }^{54}$ Morris notes three ways in which thinking contains new kinds of freedom: "thinking is free in its choice of object, thinking is free because it can invent and create, and thinking is free because it can transcend what is particular and finite" (Morris, Hans Jonas's Ethics of Responsibility, 85). The last of these categories seems to be the most paradigmatic of the freedom of human thought and the one that makes the capacity to be an ethical being possible. The ability to access universals is necessary in order to have both ethical categories and a longing for metaphysics.

${ }^{55}$ Tibaldeo, "The Heuristics of Fear: Can the Ambivalence of Fear Teach Us Anything in the Technological Age?," 233.

${ }^{56} \mathrm{MM}, 84$.

${ }^{57}$ Ibid.

${ }^{58} \operatorname{IR}, 43$.

${ }^{59}$ Tbid.

${ }^{60}$ Tbid.
} 
to the modern mind does not shy away from questions that have been deemed unanswerable and therefore avoided on the ground that such matters are fruitless. Jonas argues that philosophy should take up these questions and once again be permitted to be speculative. The dogma that theory should "steer clear of the unprovable" must no longer hold sway over contemporary philosophyy. ${ }^{61}$ Jonas's insistence on metaphysical speculation has the intended effect of encouraging humility toward our technological power out of the recognition that man is ignorant of the whole of nature.

Jonas's notion of metaphysical speculation, however, does not attempt to replace one set of dogmas with another. The point of reflective activity is not to arrive at a set of definitive answers to the riddles arising out of human life, but to encounter and hazard answers to the "ultimate questions." Questions to which no human being is likely ever to find a satisfactory answer.

Of course, every attempt to get a grip on the riddle on the universe must end in disrepute. But this must ever be risked anew, each time as a different and unique venture, and mitigated by the consolation that at least in doing so one finds oneself in good company, even in the best company of all: that of the philosophia perennis. ${ }^{62}$

The questions of the philosophia perennis-modulated and inflected by historical circumstance-provide an old form of human striving that can be taken up anew, namely the task of reflecting on the whole. It serves as an alternative to the modern form of striving, which seeks to remake man into a being without limitations. By returning us to such good company, Jonas hopes to prevent a form of philosophy, and thus human reflection, from being lost as a result of modern thought's insistence on methodology. In this way, Jonas engages in a reexamination of the fact-value distinction, showing this distinction to be misguided by being false to both the phenomenon of life and human experience.

Philosophy must be allowed to pass once again from physics to metaphysics, from the world as it is known to physicists to speculations about the "whole of reality." Jonas insists that "it is the task of philosophy to reflect on this whole." Before philosophy can reengage with this task, it must recover the perennial questions or the questions that point us toward such reflection on the whole. Jonas gives us the origin of these questions in the man's first reflections on that paradox of organic being, death. That is, metaphysical speculation arises when people first mark the passing of their ancestors with graves. Jonas writes: "With the graves, the question [of death] takes on concrete form: 'Where do I come from; where am I going?' and ultimately, "What am Ibeyond what I do and experience at a given time?"rot Questions such as these make up the philosophia perennis. Jonas insists that to philosophize about such questions again, we need not begin from the beginning ourselves, but to revisit the attempted answers of past humanity. With Jonas, we must refuse to "believe that all those great thinkers, from Plato to Spinoza, Leibniz, Hegel, and so forth, were blind and foolish, and that only we today, thanks to the Vienna Circle, have become clever and wise."65 With these great thinkers, the modern mind must "dare to ask speculative questions" and test their answers against new evidence. ${ }^{66}$

Despite the dogma of modern thought, which claims that one must remain silent where one cannot know, Jonas's hope of recovering metaphysical speculation is, paradoxically, the hope of recovering a more modest approach to the pursuit of

\footnotetext{
${ }^{61}$ MM, 192 .

${ }^{62} M M, 194$

${ }^{63} \mathrm{MM}, 193$. Jonas's emphasis.

${ }^{64} \mathrm{MM}, 83$.

${ }^{65} \mathrm{MM}, 194$

${ }^{66}$ Ibid.
} 
knowledge. His orientation toward the philosophia perennis admits the impossibility of ever attaining knowledge of the whole. As Strachan Donnelley writes, "Jonas credits us as thinkers with being natively equipped with limited or circumscribed epistemic powers which suffice for speculative philosophy, as long as the latter is critically reflective and renounces any pretension to certain and absolute truth. ${ }^{967}$ However, this is not to say that knowledge of any kind is impossible nor that tentative or historical answers cannot yield positive results. For example, Jonas praises dualism, in all its forms, from Plato to Descartes, from St. Paul to Zarathustra, for deepening the inner life of the human being ${ }^{68}$ Even if Jonas claims that these dualisms fail to capture the riddle of existence, or even the riddle of subjectivity, he maintains that these failures have provided significant insights into human existence. What Jonas hopes to foster is the outlook that the knowledge philosophy is most certain of attaining is the knowledge of ignorance.

As Jonas writes, the Socratic "I know that I know not," has "proved as a beginning of philosophy."69 This Socratic ignorance informs Jonas's attempts at metaphysical speculation. Morris writes: "Jonas's philosophical vision leads him to advocate a Socratic recognition of the limits of our wisdom accompanied by a corresponding questioning of everything, including our role in the greater realm of life."70 His metaphysical "myth" of the suffering God, for example, attempts to capture some aspect of the ontological facts and ethical implications he uncovers, but it makes no pretension of being a genuine theological account. ${ }^{71}$ Instead, the mythical cosmology and account of the suffering God serves as an example of the speculative and tentative questioning that makes the human being unique. In the end, however, Jonas does not make any claims to definitive knowledge about the whole. He thus embodies both the wonder toward the whole and awareness of the limits of human reason supported by the orientation of Socratic ignorance.

This encouragement of wonder toward the riddle of existence is motivated by the responsibility that our great power over nature demands "a new kind of humility -a humility owed, not like former humility to the smallness of our power, but to the excessive magnitude of it." ${ }^{\prime \prime 2}$ Jonas's Socratic ignorance, then, is not only motivated by his wonder toward the whole. The impetus to discover this modest orientation toward the whole derives from the fear of what man may do out of his Promethean impulses. Indeed, the posture of Socratic ignorance is to theory what the heuristics of fear is to practice; the two postures toward our knowledge of nature complement one another. An awareness of our ignorance of the whole would restrain the desire to master the physical world. The knowledge of our "ignorance of the ultimate implications becomes itself a reason for responsible restraint."73 Where the recovery of a "supreme wisdom" that makes choices about ends fails, Jonas hopes that the recovery of the seemingly lhumbler wisdom, the knowledge of ignorance, will protect man from himself. ${ }^{74}$

Jonas's greater hope, however, is that this epistemological modesty toward the whole will control the hubristic disposition of the modern project through a recovery of the "supremely useful and much needed knowledge of ends." Jonas seeks to recover the

\footnotetext{
${ }^{67}$ Strachan Donnelley, "Hans Jonas, the Philosophy of Nature, and the Ethics of Responsibility." Social Research, Vol.56, No.3 (Autumn 1989), 655.

${ }^{68}$ See, MM, 171 .

${ }^{69} P L, 210$.

${ }^{70}$ Morris, Hans Jonas's Ethics of Responsibility, 38. Morris contrasts this orientation toward philosophy with the brilliant failure of Heidegger. Although I agree with Morris's statement on the effect Jonas's mode of philosophizing has on his ethics of responsibility, this essay places more emphasis on this effect, understanding Jonas's posture of Socratic ignorance to be the theoretical counterpart to the practical "heuristics of fear."

${ }^{71}$ See, $P L, 275-277$, and MM, 189-191.

${ }^{72} \operatorname{IR}, 22$.

${ }^{73}$ Tbid.

${ }^{74}$ IR, 21.

${ }^{75} \mathrm{PL}, 210$
} 
ability of the scientist, philosopher, and more generally contemporary man, to reflect on the extrascientific question of ends-for contemporary man "denies the very existence of [wisdom's] object, namely objective value and truth. ${ }^{976}$ The recovery of the perennial questions, along with the recovery of the proper orientation toward them, are the necessary conditions for the belief that objective standards of value are available. Contemporary man can hope to manage the technological process by once again inquiring into the purpose of this process; that is, he must strive to subordinate practice to the wisdom of theory and scientific knowledge to considerations of the good. The reflective exploration of these most urgent considerations may help relieve contemporary man from his indebtedness to the technological process by urging him to reconsider questions of value under the recognition that these questions might indeed be the subject of knowledge and not merely matters of preference or opinion.

Access to such perennial philosophical questions requires philosophical theory to return to its source in ordinary human experience. Concerning Jonas's approach to philosophy, Donnelley writes: "The philosopher must take a first and final stand in the immediate experience of the self and the world and jealously guard this primary, fundamental, and complex evidence against theoretical extravagances." critiques of modern theory's dogma concerning questions of value, the epiphenomenalism promoted by materialists, and existentialism's neglect of the body, serve the purpose of turning philosophy back to man's firsthand experience of the world, which provides the substance of any genuine or serious metaphysical speculation. ${ }^{78} \mathrm{By}$ counteracting the modern tendency toward radical doubt and beginning from the point that materialistic science denies, although depends upon, ${ }^{79}$ philosophy can take up the most urgent questions of human life.

One might accuse Jonas of promoting a naïve vision of philosophy. Such a critic might claim that a confluence of historical circumstances, including conventional and linguistic constructs, mediates the cognition of human experience. Reason is bounded by its historicity and thus cannot claim any access to fundamental or perennial questions. Such historicism, Jonas would argue, is itself a construct of the modern authors of progress and the anthropology of perfectibility. Instead of denying the facts of ordinary human experience, as many modern theories of philosophical abstraction appear to do, we should consider our experience as the most fruitful starting-point of philosophyalthough always on the condition that all theories, even Jonas's philosophy of life, are tentative and open to reexamination. This trust in ordinary human experience combined with the posture that philosophical answers are tentative explains the peculiar combination of daring and modesty that constitutes Jonas's vision of philosophy. A vision best summarized by the tension between longing and unfulfillment; that is, Jonas encourages us to indulge the metaphysical longings that the dogmas of contemporary philosophy would like to neuter, yet we must be content to be unsatisfied. Philosophy, for Jonas, should hold us in a state of zetetic suspense.

\section{Conclusion}

\footnotetext{
${ }^{76}$ IR, 21.

${ }^{77}$ Donnelley, "Hans Jonas, the Phillosophy of Nature, and the Ethics of Responsibility," 654 .

${ }^{78}$ Jonas's own philosophical writings, particularly his writings on biology, have an ambiguous method that borders both phenomenology and metaphysics. For a helpful article on this issue, see Eric Pommier, "Hans Jonas's Biological Philosophy: Metaphysics or Phenomenology?" International Philosophical Quarterly, Vol. 57 , No.4. (December 2017): 453-469, https://doi.org/10.5840/ipq201791894. Any hesitancy Jonas has toward the metaphysical or phenomenological status of his method may result from an intentional blurring of such distinctions. This distinction between phenomenology and metaphysics appears to be a consequence of modem dualism and its skepticism toward the senses (phenomenology being a reaction against this skepticism). Any true metaphysics, for Jonas, would have to take into account the perspective of the thinking organism, and thus begin from a sort of phenomenological analysis, i.e., an examination of human experience. ${ }^{79}$ See, $P L, 210$
} 
Humanity's technological power has grown immensely during the same period in which philosophy has renounced metaphysical speculations and refused to indulge the philosopher's metaphysical longings. Indeed, "we need wisdom most when we believe in it the least. ${ }^{\mathrm{r}} \mathrm{P0}$ Contemporary man denies the existence of wisdom either because he is convinced of modern dualism's success in ensuring technological progress or because he despairs at the disenchantment of the world and is persuaded of the historicity of all human thought. Jonas seeks a path between the excessive hopes of the modern project and the despair of modern nihilism. The critique of progress is the first step toward freeing us from the technological process and the "cave" of modernity. This critique opens the modern mind to the alternative ethics of responsibility, the emphasis on metaphysical speculation, and the engagement with the concerns of political philosophy. Jonas's philosophy of life is the bridge between this critique and the reorientation of ethics and thought. The examination of this bridge between the critique of progress and Jonas's ethical theory shows how the ethics of responsibility depends upon Jonas's idea of proper philosophic activity. That is, a less hulbristic ethical theory depends upon a more modest philosophical posture. To quote Jonas's good friend, the posture of Socratic ignorance encourages us to "think what we are doing." Only by engaging with our longings for metaphysical speculation, and with the questions that most concern human existence, will the ethics of responsibility find a fruitful soil to take root.

Being heretical regarding modern philosophy's dogmas will support us in rethinking our relationship with nature, our place within creation, and help us proceed cautiously into the future. Yet Jonas shows that we can only hope to reorient philosophy by engaging with the ideas and questions underlying modern philosophy and the modern project of progress. Jonas looks to the foundations of modernity and shows how the answers these early modern thinkers gave to the most urgent human questionsnamely the questions conceming how one ought to live, man's place in nature, and what can be known-failed to account for the whole because they were unable to account for biological life. Yet by reading and thinking with these founders of our modern world, Jonas offers us the possibility of uncovering these most critical questions for ourselves. And he gives humanity an imperative to do so. For the normative value of philosophical activity is grounded in our biological being, and through the search for an objective set of values, humanity may hope to master its mastery over nature. At the very least, a modest yet questioning orientation toward the whole, characterized by a knowledge of ignorance, will aid humanity in its hopes of proceeding into the future with fear, humility, and caution.

Although fear, humility, and caution have a central place in Jonas's ethics of responsibility, he does not leave us devoid of hope-for Jonas knows that hope is the well-spring of action. This hope is found, fittingly enough, in the biological facts present in all organisms, namely natality and mortality. In the condition of natality and the natural cycle of human youthfulness humanity finds its "ever-renewed beginning" that "may well be its hope." Y2 Youthfulness comes with the "unique privilege of seeing the world for the first and with new eyes," providing the experience of wonder, "the beginning of philosophy."r3 Jonas thus provides us with the hope that man can still become a responsible steward of being because there exists in the conditions of his nature enduring access to the perennial questions of life.

\title{
Referências
}

\author{
${ }^{80} I R, 21$. \\ ${ }^{81}$ Hannah Arendt, The Human Condition, (Chicago, IL: University of Chicago Press, 1998), 5. \\ ${ }^{82}$ IR, 19 . \\ ${ }^{83}$ Ibid.
}


Arendt, Hannah. The Human Condition. Chicago, IL: University of Chicago Press. 1998.

Chang, Kenneth. "Elon Musk's Plan: Get Humans to Mars and Beyond." The New York Times, September, 28, 2016. https://www.nytimes.com/2016/09/28/science/elon-muskspacex-mars-exploration.html.

Donnelley, Strachan. "Hans Jonas, the Philosophy of Nature, and the Ethics of Responsibility." Social Research, Vol.56, No.3 (Autumn 1989), 635-657.

"Der Spiegel interview with Martin Heidegger," translated by Jerome Veith. The Heidegger Reader. Bloomington, IN; Indiana University Press, 2009. 313-333.

Horn, Dara. "The Men Who Want to Live Forever." The New York Times, January 25, 2018. immortality.html. hittps://www.nytimes.com/2018/01/25/opinion/sunday/silicon-valley-

Jonas, Hans. The Imperative of Responsibility: In Search of an Ethics for the Technological Age. Chicago, IL: University of Chicago Press. 1984.

Jonas Hans. Mortality and Morality: A Search for the Good After Auschwitz, ed. Lawrence Vogel. Chicago, IL: Northwestern University Press. 1996.

Jonas, Hans. The Phenomenon of Life, ed. Lawrence Vogel. Evanston, IL: Northwestern University Press. 2001.

Kant, Immanuel, ed. Paul Guyer and Allen Wood. Critique of the Power of Judgment. New York, NY: Cambridge University Press. 2000.

Kant, Immanuel. Critique of Pure Reason, ed. Paul Guyer and Allen Wood. New York, NY: Cambridge University Press. 1992.

Kennington, Richard. On Modern Origins: Essays in Early Modern Philosophy. Lanham, MD: Lexington Books. 2004.

Koyré, Alexandre. From the Closed World to the Infinite Universe. Baltimore, MD: The John Hopkins Press. 1957.

Morris, Theresa. Hans Jonas's Ethics of Responsibility. Albany, NY: SUNY Press. 2013.

Pommier, Eric. "Hans Jonas's Biological Philosophy: Metaphysics or Phenomenology?" International Philosophical Quarterly, Vol. 57, No.4. (December 2017): 453-469. htttps://doi.org/10.5840/ipq201791894.

Solon, Olivia."Priscilla Chan and Mark Zuckerberg aim to "cure, prevent and manage all disease." The Guardian, September 2016. lhttps:/www.theguardian.com/technology/2016/sep/21/mark-zuckerberg-priscilla-chanend-disease.

Tibaldeo, Roberto Franzini. "The Heuristics of Fear. Can the Ambivalence of Fear Teach Us Anything in the Technological Age?" Ethics in Progress, Vol.6, No.1. (2015): 225-238. hittps://doi.org/10.14746/eip.2015.1.9.

Vogel, Lawrence. "Hans Jonas's Diagnosis of Nihilism: The Case of Heidegger." International Journal of Philosophical Studies. 3.1 (1995): 55-72. https://doi.org/10.1080/09672559508570803. 